\title{
A Study to Assess the Effectiveness of Video Assisted Teaching Programme on Warning Signs of Pregnancy among Primi Gravid Women Attending Outpatient Department of Primary Health Centre, Ariyankuppam at Puducherry \\ ${ }^{*}$ Ms.Malathi.K, ${ }^{* *}$ Annie Annal.M \& ${ }^{* * *}$ Anitha.B
}

\begin{abstract}
:
Objectives: To evaluate the Effectiveness of Video Assisted Teaching Programme on Warning Signs of Pregnancy among primi Gravid Women. Method: Pre-experimental with one group pre-test-post-test design adopted for this study among 60 primi gravid women. Results: The findings revealed that the mean pre test score was 8.17 and post test knowledge score was 25.6 with standard deviation of pre test score 1.586 and post test knowledge score 2.330 which was found statistically highly significant at $p<0.05$ level. It implied that Video Assisted Teaching Programme on Warning Signs of Pregnancy was effective to improve knowledge on warning signs of pregnancy among primi Gravid Women. Conclusion: The Video Assisted Teaching Programme was found highly significant in enhancing the knowledge of primi gravid women on warning signs of Pregnancy at $p<0.05$ level.
\end{abstract}

Key words: Evaluate, Effectiveness, Video Assisted Teaching Programme, warning signs of Pregnancy

\section{INTRODUCTION}

Pregnancy is one of the most beautiful phase for women which along with bringing a feeling of bliss and happiness, also brings with it a hope and prayer that the child is born healthy and fit. Sometimes it may be complicated by a variety of disorders and conditions that can be profoundly affect the women and her fetus. The disorders, which predate pregnancy, are important because of the way in which pregnancy affects them or the treatment for the disorders that affect the pregnancy. Warning signs means which are the signs or symptoms that create the life treating situation for the mother and fetus.

\section{OBJECTIVES:}

* To assess the knowledge on Warning signs of Pregnancy among primi gravid women during pre test.

* To evaluate the effectiveness of Video assisted teaching programme by comparing pre \& post test score.

* To find out the association between the knowledgeon warning signs of pregnancy and selected demographic variables of primi gravid women 


\section{HYPOTHESES:}

H1: There is a significant difference between the pre test and post test scores.

$\mathrm{H} 2$ :There is a significant relationship between pre test knowledge score with selected demographic variables such as age, religion, education, monthly family income, type of family, area of residence, gestational age, source of information.

\section{METHODOLOGY:}

Research approach used for the study was Quantitative Research Approach and the Research design was Pre-Experimental with one group pre test- post- test design. The study was conducted in Primary Health Centre, Ariyankuppam, Puducherry. The Sample size was 60 primi gravid women.
The samples were selected by Simple Random Sampling Technique based on the inclusion criteria. Pre-test was done to assess the knowledge on warning signs of pregnancy by structured knowledge questionnaire. After pre-test, video assisted teaching programme on warning signs of pregnancy which consists of Introduction, Meaning, List of Warning signs of Pregnancy, Causes, Signs and Symptoms, Prevention and Management, Complication and Conclusion was provided. Post-test was conducted after the gap of 7 days of Structured Teaching Programme. The data were analyzed by using descriptive and inferential statistics like frequency, percentage, mean, standard deviation, paired T-Test and ChiSquare test.

\section{RESULTS}

Distribution of level of knowledge on warning signs of pregnancy among primi gravid women

\begin{tabular}{|l|l|c|c|c|c|}
\hline S.No & \multicolumn{1}{c|}{$\begin{array}{c}\text { Level of } \\
\text { Knowledge }\end{array}$} & \multicolumn{2}{|c|}{ Pre test } & \multicolumn{2}{c|}{ Post test } \\
\cline { 3 - 6 } & & $\boldsymbol{n}$ & $\%$ & $\boldsymbol{n}$ & $\%$ \\
\hline 1. & $\begin{array}{l}\text { Adequate } \\
\text { Knowledge }\end{array}$ & 8 & 13 & 48 & 80 \\
\hline 2. & $\begin{array}{l}\text { Moderately } \\
\text { Adequate } \\
\text { Knowledge }\end{array}$ & 10 & 17 & 12 & 20 \\
\hline 3. & $\begin{array}{l}\text { Inadequate } \\
\text { knowledge }\end{array}$ & 42 & 70 & - & 0 \\
\hline
\end{tabular}

Table 1 shows that distribution of level of knowledge on warning signs of pregnancy in primi gravid women during pretest and post test. Out of 60 samples, most of them $42(70 \%)$ had inadequate knowledge, $10(17 \%)$ had moderately adequate knowledge, and $8(13 \%)$ had adequate knowledge in pre test and in the post test, most of them 48 $(80 \%)$ had adequate knowledge, $12(20 \%)$ had moderately adequate knowledge, and none of them had inadequate knowledge.

It was inferred that most of the primi gravid women had inadequate knowledge in pre test and most of the women had adequate knowledge in post test. 


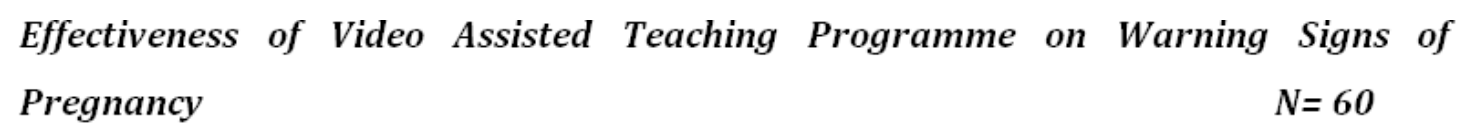

\begin{tabular}{|c|c|c|c|c|c|c|}
\hline S.No & Variables & Mean & $\begin{array}{c}\text { Standard } \\
\text { Deviation }\end{array}$ & $\begin{array}{c}\text { Mean } \\
\text { difference }\end{array}$ & $\begin{array}{c}\text { Paired 't' } \\
\text { value }\end{array}$ & P value \\
\hline 1. & Pre test & 8.17 & 1.586 & & & \\
\cline { 1 - 4 } 2. & Post test & 25.6 & 2.330 & 17.433 & 43.803 & $\begin{array}{c}.000^{* * *} \\
\text { HS }\end{array}$ \\
\hline
\end{tabular}

${ }^{*}$-Highly significant $P<0.001$

The mean pre test knowledge score was 8.17 and post test knowledge score was The standard deviation of pre test knowledge score was 1.586 and post test knowledge score was 2.330 . The obtained paired ' $\mathrm{t}$ ' value was 43.803 and $p$ value was .000. It was significant at $\mathrm{p}<0.05 \%$ level. Hence the stated hypothesis was accepted.

\section{Association between Pretest Knowledge on warning signs of pregnancy and demographic variables.}

The study revealed that there was a significant association between the knowledge scores of the mothers with age, education, type of the family, area of the residence and family income among primi gravid mothers.

\section{RECOMMENDATIONS}

The study can be done with control group

$>$ A Comparative study can be conducted among rural and urban areas of primi gravid women

$>$ Study can be conducted to assess the practices by providing education on warning signs of pregnancy

$>$ Health professional can be instructed to conduct the health education programme on warning signs of pregnancy.

\section{Conclusion:}

The study reveals that the Video Assisted Teaching Programme was effective in improving the knowledge on Warning signs of Pregnancy among primi gravid women. The knowledge of primi gravid women on Warning signs of Pregnancy helps to prevent the early complications among primi gravid women. So we can promote the utilization of Video Assisted Teaching method to improve the knowledge on Warning signs of Pregnancy among primi gravid women

\section{REFERENCES:}

1. Fraser M.Diane\& Cooper A. Margaret Myles Text Book for Midwives. 14thedn. New York: Churchill Livingstone: 2003.

2. Dutta DC. Text Book of Obstetrics.

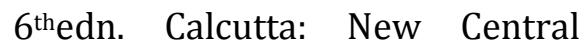
Book Agency: 2004

3. Jacob Annamma. A Comprehensive Textbook of Midwifery. $2^{\text {ndedn. }}$ New Delhi: Jaypee Medical Publishers: 2008

4. Basavanthappa B.T. Text book of Midwifery and Reproductive Health Nursing .Istedn. New Delhi: Jaypee Brothers Medical Publishers Ltd: 2006

5. Lowdermilk Leonard Deitra\& Perry E. Shannon Maternity and Womens Health Care. $6^{\text {thedn. }}$ 